\title{
Sulphate removal from mine water by precipitation as ettringite by newly developed electrochemical aluminium dosing method
}

\author{
Emma-Tuulia Nurmesniemi*, Tao Hu, Kyösti Rajaniemi, Ulla Lassi \\ Research Unit of Sustainable Chemistry, University of Oulu, P.O. Box: 4300, FI-90014 Oulu, Finland, \\ emails: emma-tuulia.nurmesniemi@oulu.fi (E.-T. Nurmesniemi), tao.hu.oulu.fi (T. Hu), \\ kyosti.rajaniemi@oulu.fi (K.Rajaniemi), ulla.lassi@oulu.fi (U. Lassi)
}

Received 4 August 2020; Accepted 7 December 2020

\begin{abstract}
A B S T R A C T
Precipitation as ettringite $\left(\mathrm{Ca}_{6} \mathrm{Al}_{2}\left(\mathrm{SO}_{4}\right)_{3}(\mathrm{OH})_{12} \cdot 26 \mathrm{H}_{2} \mathrm{O}\right)$ is an effective method for sulphate removal from mine water. The addition of calcium hydroxide and aluminium to sulphate-containing mine water in stoichiometric amounts induces an increase in $\mathrm{pH}$ to approximately 12.5 , leading to the precipitation of ettringite. Typically, aluminium salts are used as the source of aluminium; however, in this research, an electrochemical dosage of aluminium was used, and the results were compared with the results of chemical ettringite precipitation as well as the results of computational simulations of sulphate removal. The mine water sulphate concentration was reduced $99.0 \%$ and $98.6 \%$ from the initial $1,060 \pm 20 \mathrm{mg} \mathrm{L}^{-1}$ using a current density of $28 \mathrm{~mA} \mathrm{~cm}^{-2}$ in electrochemical aluminium dosing and chemical aluminium dosing, respectively, which was close to the theoretical $100 \%$ sulphate removal. When using the current density of $28 \mathrm{~mA} \mathrm{~cm}^{-2}$ in the electrochemical aluminium dosing, the recovered ettringite purity was $92.5 \%$, which was almost the same as the $92.6 \%$ purity in the chemical aluminium dosing characterised with X-ray diffraction and Rietveld analysis. The results indicate that the electrochemical dosing of aluminium could be an alternative to aluminium salt application in ettringite precipitation.
\end{abstract}

Keywords: Ettringite precipitation; Sulphate removal; Mine water; Electrochemistry; Modelling

\section{Introduction}

Acid mine drainage is produced in both active mines and following mine closure [1] and may contain over ten thousand $\mathrm{mg} \mathrm{L}^{-1}$ of sulphate [2,3]. Sulphate has both direct and indirect effects on aquatic ecosystems [4]. It causes freshwater salinization, which is detrimental to freshwater organisms that can tolerate only certain levels of water salinity [5]. In addition, sulphate-rich mine discharge water can result in the permanent stratification of the receiving lake, which can then interfere with nutrient and oxygen transfer within the lake [6,7]. Sulphate can also be microbially reduced to sulphide via sulphate-reducing bacteria. Sulphide causes toxicity via the formation of hydrogen sulphide [8].

* Corresponding author.
Sulphate removal technologies can be classified as active or passive. Active technologies require the continuous addition of chemicals as well as maintenance and monitoring, whereas passive technologies utilise natural water flow along with natural chemical and biological processes [9]. Active methods for sulphate removal from mine waters include precipitation (as gypsum, ettringite, or barite), adsorption (various materials have been studied, but no commercial adsorbents are available yet), ion-exchange (GYP-CIX and Sulf-IX processes), active biological treatment processes (sulphidogenic bioreactors), and membrane technologies [10]. Constructed or natural wetlands and bioreactors are passive sulphate removal technologies [10].

Sulphate precipitation as ettringite [11-16] is a modification of the high $\mathrm{pH}(>11)$ lime precipitation process [17]. 
With precipitation as ettringite, it is possible to reach very low residual sulphate concentrations-even below the drinking water guidelines in Finland, which is $250 \mathrm{mg} \mathrm{L}^{-1}$ [18-20]. The addition of calcium hydroxide and aluminium to sulphate-containing mine water in stoichiometric amounts induces an increase in $\mathrm{pH}$ to a value of approximately 12.5 , leading to the precipitation of ettringite. The purified water can be treated with $\mathrm{CO}_{2}$ precipitating calcite in order to lower the $\mathrm{pH}$ to below the discharge limits. The ettringite sludges formed are voluminous; however, denser sludges can be achieved by recycling some of the sludge using a high-density sludge process [15]. Polymers can be used to aid in the dewatering of formed sludge and to improve the floc strength. Recycling ettringite sludge is more cost-effective than recycling gypsum sludge, which is formed in traditional mine water treatment, as aluminium reagents are more expensive than lime. Formed ettringite can be decomposed to regenerate aluminium or possibly used as a sorbent for pollutants, such as arsenic [22].

In ettringite precipitation, calcium is typically dosed as calcium oxide/calcium hydroxide, and aluminium is typically dosed as aluminium salt, such as sodium aluminate, aluminium hydroxide, aluminium chloride, aluminium nitrate, and polyaluminium chloride [15]. A patent exists that describes a method in which sulphate-containing water is first treated with lime in order to precipitate part of sulphate as gypsum, which is then followed by electrocoagulation using an aluminium or iron sacrificial anode in order to precipitate the remaining sulphate as ettringite, aluminium sulphate hydroxides, and/or iron-aluminium sulphate hydroxides [21]. To our knowledge, there is no published scientific research on sulphate removal that uses aluminium dosing via electrochemical dissolution together with chemical lime dosing, leading to high-purity ettringite precipitation. We reported our preliminary results of electrochemical aluminium dosage in ettringite precipitation at a conference recently [22]. The aim of this research was to evaluate ettringite precipitation using electrochemical aluminium dosing together with calcium hydroxide dosing by comparing the results with those of chemical aluminium dosing with calcium hydroxide dosing as well as computational simulations of sulphate removal. Also, the operational cost, as well as the purity and stability of the ettringite solids formed using electrochemical and chemical aluminium dosing together with calcium hydroxide, was investigated. Additionally, the kinetics of sulphate removal using ettringite precipitation were studied.

\section{Materials and methods}

\subsection{Mine water and chemicals}

The mine effluent sample used in the precipitation experiments was drainage water from an underground gold mine with $\mathrm{pH} \approx 8$. The drainage water had been treated with ferric sulphate at the mine site and had been sampled after pond settling. The initial mine water sulphate concentration was $1,060 \mathrm{mg} \mathrm{L}^{-1}$. Analysis of the other components in the different batches of the same mine water is presented in [23]. Hydrated lime $\left(\mathrm{Ca}(\mathrm{OH})_{2}\right.$ SMA Mineral 93.8\%) was used in the precipitation experiments as a $20 \%$ slurry diluted in deionized water. Sodium aluminate (Kemira FennoFloc SA $84,35 \%-45 \% \mathrm{NaAlO}_{2}$ ) was used as an aluminium source in the chemical aluminium dosing experiments. Aluminium type 6101 plates [24] were used as the aluminium source in the electrochemical aluminium dosing.

\subsection{Experiments using electrochemical aluminium dosing together with calcium hydroxide}

Electrochemical aluminium dosing experiments were conducted using a $2 \mathrm{~L}$ reactor with a $1.6 \mathrm{~L}$ mine water sample volume for each experiment. The experiments were conducted at room temperature, but the temperature increased during the operation, with 1 and 2 A currents increasing to $30^{\circ} \mathrm{C}$ and $35^{\circ} \mathrm{C}$, respectively. The temperature decreased to room temperature when the power supply was switched off. A schematic illustration of the system is shown in Fig. 1a.

Both the anode and cathode were aluminium plates type 6101 [24]. The electrodes were $1 \mathrm{~cm}$-thick square plates with an exposed electrode surface area of $70 \mathrm{~cm}^{2}$. The distance between the electrodes was $3 \mathrm{~mm}$ in the experiments. The following half-cell reactions occurred at the anode (Eq. (1)) and cathode (Eq. (2)) [25-27]:

$$
\begin{aligned}
& \mathrm{Al}(\mathrm{s}) \rightarrow \mathrm{Al}^{3+}(\mathrm{aq})+3 \mathrm{e}^{-} \\
& 2 \mathrm{H}_{2} \mathrm{O}(\mathrm{l})+2 \mathrm{e}^{-} \rightarrow \mathrm{H}_{2}(\mathrm{~g})+2 \mathrm{OH}^{-}(\mathrm{aq})
\end{aligned}
$$

First, calcium hydroxide was dosed as slurry. After that aluminium plates were inserted in water and the power supply was switched on, calcium (from the calcium hydroxide) and aluminium were dosed in stoichiometric amounts to sulphate-containing mine water to achieve optimum ettringite precipitation conditions (6:2:3 for Ca:Al: $\mathrm{SO}_{4}$ ). The theoretical amount of dissolved aluminium was calculated from Eq. (3) [28], where $m_{t}$ is the theoretical amount of dissolved aluminium $\left(\mathrm{g} \mathrm{cm}^{-2}\right), M_{\mathrm{Al}}$ is the molar weight of aluminium $\left(26.98 \mathrm{~g} \mathrm{~mol}^{-1}\right), I$ is the electric current $\left(\mathrm{A} \mathrm{cm}^{-2}\right)$, $t$ is time (s), $z$ is the number of electrons transferred in the reaction (3), and $F$ is the Faraday constant $\left(96,485 \mathrm{C} \mathrm{mol}^{-1}\right)$.

$m_{t}=\frac{M_{\mathrm{Al}} \cdot I \cdot t}{z \cdot F}$

The power supply was operated in a constant current mode with an applied current of 2 or 1 A for 40 or $80 \mathrm{~min}$, respectively. The submerged plate surface area was $70 \mathrm{~cm}^{2}$, and thus the resulting current densities were 28 or $14 \mathrm{~mA} \mathrm{~cm}^{-2}$, respectively. The $\mathrm{pH}$ rose to approximately 12.5 with the calcium hydroxide dosing and stayed quite constant in the electrochemical aluminium dosing experiments. In electrocoagulation, the $\mathrm{pH}$ usually increases to approximately $\mathrm{pH}=10$ as the hydroxide ions are formed (Eq. (2)). However, since the $\mathrm{pH}$ was raised to approximately 12.5 using calcium hydroxide, like in the chemical ettringite precipitation experiments, this effect was not observed. The samples were mixed at the rate of $50 \mathrm{rpm}$ with magnetic stirring for a total of $4 \mathrm{~h}$, which was followed by settling. The samples were filtrated $24 \mathrm{~h}$ after the start of the experiment. 
a)

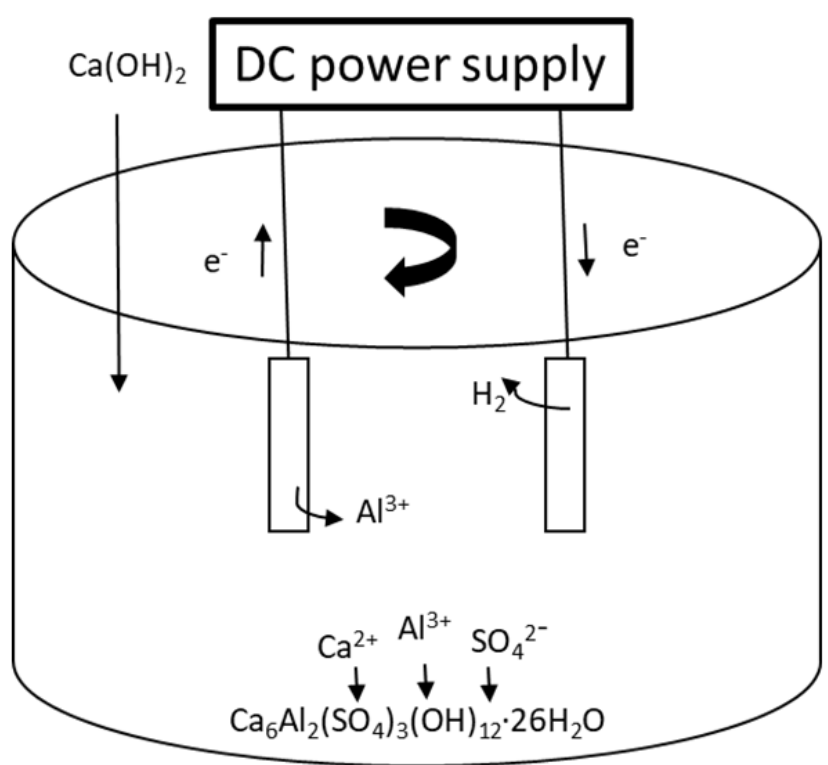

b)

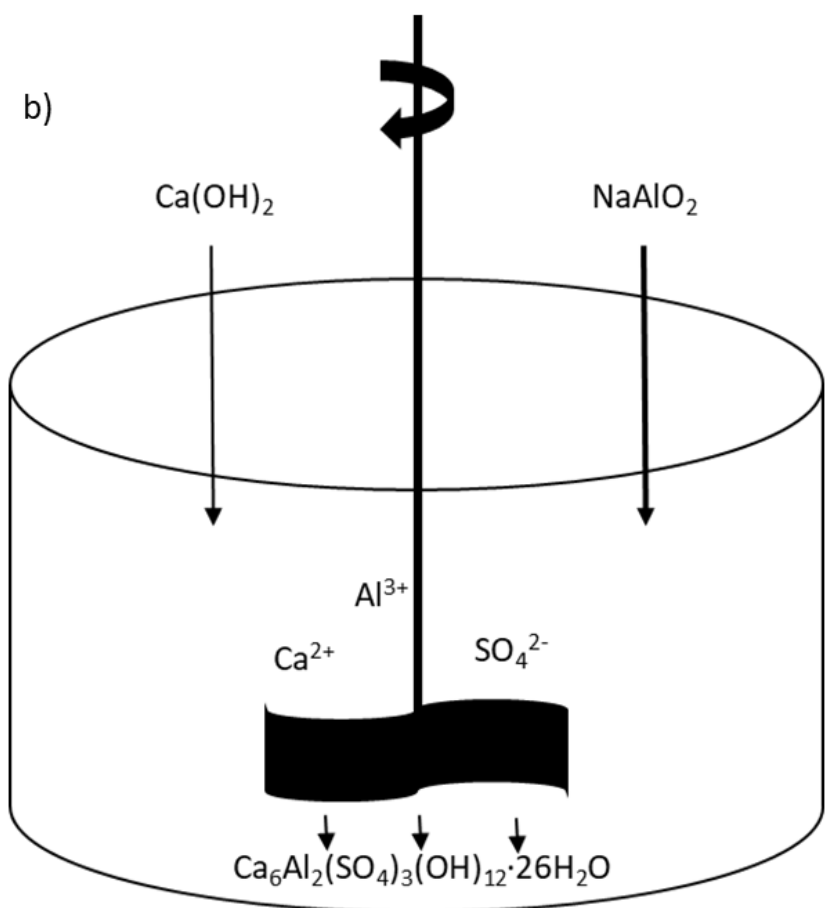

Fig. 1. Schematic illustration of the reactor used in the (a) electrochemical aluminium dosage experiments and (b) chemical aluminium dosage experiments.

\subsection{Experiments using chemical aluminium dosing together with calcium hydroxide}

A $2 \mathrm{~L}$ reactor with a paddle stirrer and stators was used for the chemical precipitation experiments (Fig. 1b). The mine water sample volume was $1.6 \mathrm{~L}$ for each experiment, and the experiments were conducted at room temperature. First, calcium hydroxide as slurry was added and, after that, sodium aluminate was added to the mine water. Calcium (from calcium hydroxide) and aluminium (from sodium aluminate) were dosed in stoichiometric amounts to sulphate-containing mine water to achieve optimum ettringite precipitation conditions. The $\mathrm{pH}$ in the chemical aluminium dosing experiments was approximately 12.5. The samples were mixed at the rate of $50 \mathrm{rpm}$ using a paddle stirrer for $4 \mathrm{~h}$, which was followed by settling. The samples were filtrated $24 \mathrm{~h}$ after the start of the experiment.

\subsection{Leaching experiments}

The stability of the precipitates formed via electrochemical and chemical ettringite precipitation was studied by conducting leaching experiments. The leaching experiments were conducted based on standard SFS-EN 12457-2 [29]. Deviating from the standard, the dried precipitates were crushed and sieved to a particle size $<1 \mathrm{~mm}$ instead of $<4 \mathrm{~mm}$, and smaller sample size was used. Smaller particles have bigger surface areas. Thus, a reduction in the particle size of the precipitant is expected to result in higher leaching. $2 \mathrm{~g}$ of each precipitate were weighed into $50 \mathrm{~mL}$ centrifuge vials, and $20 \mathrm{ml}$ of deionized water was added to each vial. The vials were agitated at $300 \mathrm{rpm}$ for $24 \mathrm{~h}$ in a reciprocal shaker (POL-EKO LS 700). After shaking, the samples were left to settle for $15 \mathrm{~min}$. Each precipitate was tested in duplicate, and the analysis results were given as an average.

\subsection{Analytical methods}

After settling, the water samples from the supernatant were taken for $\mathrm{Al}, \mathrm{Ca}$, and $\mathrm{S}$ analysis. All effluent samples were vacuum-filtered through $0.45 \mu \mathrm{m}$ cellulose nitrate membrane filters (Sartorius) prior to $\mathrm{Al}, \mathrm{Ca}$, and $\mathrm{S}$ analysis with ICP-OES. The $\mathrm{pH}$ was measured from the effluent samples using a $\mathrm{HACH} \mathrm{HQ} 40 \mathrm{~d}$ portable meter. The precipitates were filtered with Schleicher \& Schuell black ribbon filter paper via vacuum filtration. Then, they were air-dried, weighed, crushed, sieved, and stored in a desiccator. The dried samples were then analysed with the $X^{\prime}$ Pert PRO X-ray Diffraction System produced by PANalytical B.V. (The Netherlands). The measurements were performed with $\mathrm{Cu} \mathrm{K} \alpha(1.5406 \AA)$ at $40 \mathrm{~mA}$ and $45 \mathrm{kV}$ in the $2 \theta$ range of $5^{\circ}-70^{\circ}$ and with a scan speed of $0.0235^{\circ} \mathrm{s}^{-1}$. The analysis was conducted using the HighScore program and the Rietveld method.

\subsection{Calculations}

Thermodynamic equilibrium calculations were performed using the MINEQL+ version 5.0 software. MINEQL+ solves mass balance calculations via the Newton-Raphson method using equilibrium constants from a thermodynamic database. The database was extended with an ettringite solubility constant $\left(K=10^{-56.4}\right)$ obtained with modification 
from an experimentally determined equilibrium constant by Myneni et al. [30], which is explained in more detail by Tolonen et al. [19]. There is variation in the ettringite solubility product values reported in the literature, and the value used in the calculations has an effect on the modelling results. The initial sulphate, calcium, and aluminium concentrations as well as the temperature $\left(25^{\circ} \mathrm{C}\right)$ used in the calculations were chosen to model the experimental conditions.

The kinetics of sulphate removal using ettringite precipitation were studied. The sulphate concentration during this ettringite precipitation was as follows. The order of the ettringite precipitation reaction with respect to sulphate concentration was determined. Rate law refers to the rate of a reaction in terms of the concentrations of the chemical species. The exponent denotes the order of the reaction. The rate constant, $k$, is a proportionality constant that refers to the reaction rate of the concentration of the reacting substances. Eqs. (4) and (5) show the first-order and second-order rate laws. The solutions in Eqs. (4) and (5) are given in Eqs. (6) and (7) [31]. Eqs. (6) and (7) [31] were fitted to the experimental data using nonlinear curve-fitting by OriginPro. The fit of the first-order and second-order kinetic models was evaluated based on the correlation coefficient $\left(R^{2}\right)$ values.

$v=-\frac{d c_{\text {sulphate }}}{d t}=k c_{\text {sulphate }}$

$v=-\frac{d c_{\text {sulphate }}}{d t}=k c_{\text {sulphate }}^{2}$

$c_{\text {sulphate }}=c_{0} e^{-k t}$

$c_{\text {sulphate }}=\frac{1}{\left(\left(\frac{1}{c_{0}}\right)+k t\right)}$

where $c_{\text {sulphate }}$ is the concentration of sulphate, $c_{0}$ is the initial concentration of sulphate, $k$ is the rate coefficient, and $t$ is time.

The operating cost of electrochemical aluminium dosing was compared with that of chemical aluminium dosing. In the electrochemical aluminium dosing, the aluminium cost was calculated from the price of a type 6101 aluminium sheet. In the chemical aluminium dosing, the sodium aluminate price was used. For both, the lime price was used. Other costs, such as shipping, installation, and maintenance costs, as well as landfill disposal costs or the possible sales of the formed ettringite precipitates were not included in the cost comparison. The operating costs of ettringite precipitation with electrochemical and chemical aluminium dosing were calculated using Eqs. (8) and (9), respectively [32].

$\mathrm{OC}_{\text {electrochemical }}=a \cdot C_{\text {energy }}+b \cdot C_{\text {electrode }}+c \cdot C_{\text {lime }}$

$\mathrm{OC}_{\text {chemical }}=c \cdot C_{\text {lime }}+d \cdot C_{\text {sodium aluminate }}$

where $a$ is the energy price $\left(€ \mathrm{kWh}^{-1}\right), C_{\text {energy }}$ is the energy consumption $\left(\mathrm{kWh} \mathrm{m}^{-3}\right), b$ is the electrode material price $\left(€ \mathrm{~kg}^{-1}\right), C_{\text {electrode }}$ is the electrode consumption $\left(\mathrm{kg} \mathrm{m}^{-3}\right)$, $C$ is the lime price $\left(€ \mathrm{~kg}^{-1}\right), C_{\text {lime }}$ is the lime consumption $(\mathrm{kg}), d$ is the sodium aluminate price $\left(€ \mathrm{~kg}^{-1}\right)$, and $C_{\text {sodium }}$ aluminate is the sodium aluminate consumption. The energy consumption $\left(C_{\text {energy }}\right)$ of the electrochemical aluminium dissolution was calculated from Eq. (10) [32].

$C_{\text {energy }}=\frac{U \cdot I \cdot t}{V}$

where $U$ is the voltage $(\mathrm{V}), I$ is the current (A), $t$ is time (h), and $V$ is the mine water volume $\left(\mathrm{m}^{3}\right)$.

\section{Results and discussion}

\subsection{Modelling of ettringite precipitation}

Ettringite precipitation as a function of $\mathrm{pH}$ is modelled (Fig. 2). When the saturation index (SI) has a negative value, the system is undersaturated with respect to the solid. When the SI is zero, the system is in equilibrium with the solid. When the SI has a positive value, the system is oversaturated with respect to the solid. According to the thermodynamic calculations, ettringite has a positive SI value and is able to precipitate starting at $\mathrm{pH} \geq 10.5$ (Fig. 2a). At $\mathrm{pH}$ 12.5, ettringite saturation is at its maximum value (Fig. 2a). The calculations indicated that, at $\mathrm{pH} 12.5$, all sulphate was in the form of ettringite (Fig. 2b). The calculated results are in line with the ettringite stability $\mathrm{pH}$ area 10.5-13 [33].

\subsection{Kinetics of ettringite precipitation}

The sulphate concentration was followed by taking samples at specific times throughout the chemical ettringite precipitation experiment and then measuring sulphate concentration from the samples. Fig. 3 shows a curve of the ettringite precipitation. Specifically, the ettringite precipitation is quite rapid, and the sulphate concentration reaches equilibrium at only $30 \mathrm{~min}$. However, in order to form crystalline ettringite for the X-diffraction (XRD) analysis, precipitation experiments with $4 \mathrm{~h}$ mixing followed by overnight settling were conducted. Both the first- and second-order kinetic models provided a good fit of the experimental data with the correlation coefficients $R^{2}=0.998$ and $R^{2}=0.990$, respectively (Fig. 3 ). The fit of the first-order kinetic model was slightly better, which indicates that the ettringite precipitation reaction is first order with respect to the sulphate concentration. The fit resulted in a rate coefficient value of $k=0.00452 \mathrm{~s}^{-1}$, which indicates the amount of sulphate transformed into ettringite each second.

\subsection{Sulphate removal from mine water}

Both electrochemical and chemical aluminium dosing reduced the sulphate concentration of the mine water from the initial value of $1,060 \pm 20 \mathrm{mg} \mathrm{L}^{-1}$ to below the drinking water guideline in Finland (i.e., $250 \mathrm{mg} \mathrm{L}^{-1}$ ). Residual sulphate concentrations were 10,15 , and $66 \mathrm{mg} \mathrm{L}^{-1}$ with the electrochemical aluminium dosage (2 A current), chemical aluminium dosage, and electrochemical aluminium dosage (1 A current), respectively. High sulphate removal values of 


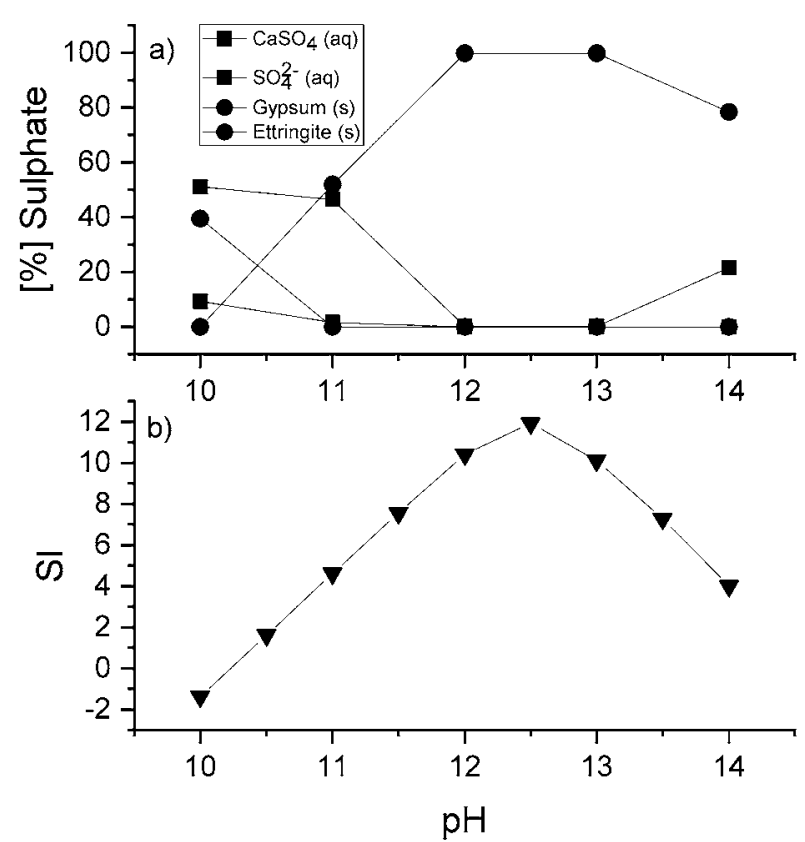

Fig. 2. (a) Sulphate speciation and (b) saturation index of ettringite as a function of $\mathrm{pH}$.

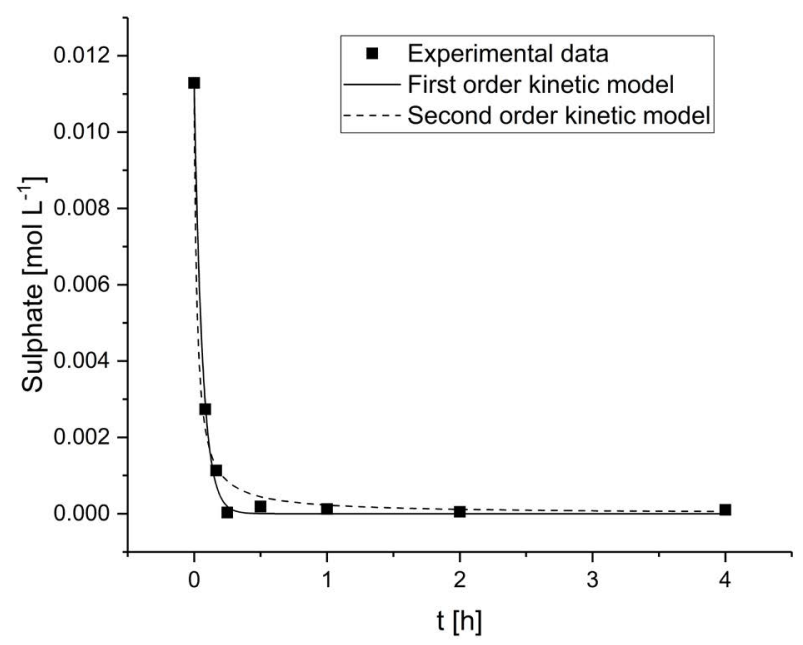

Fig. 3. Variation in the $\mathrm{SO}_{4}^{2-}$ concentration during chemical ettringite precipitation experiment. The solid line is the fit of the first-order kinetic model and the dashed line the fit of the second-order kinetic model (Eqs. (6) and (7), respectively) to the experimental data.

$99.0 \%, 98.6 \%$, and $93.8 \%$ were found for the electrochemical aluminium dosage (2 A current), chemical aluminium dosage, and electrochemical aluminium dosage (1 A current), respectively (Fig. 4). Sulphate removal close to the theoretical $100 \%$ value modelled with MINEQL+, was obtained using both chemical and electrochemical (2 A current) aluminium dosing.

An increase in the applied electric current resulted in an increase in sulphate removal as well as ettringite purity,

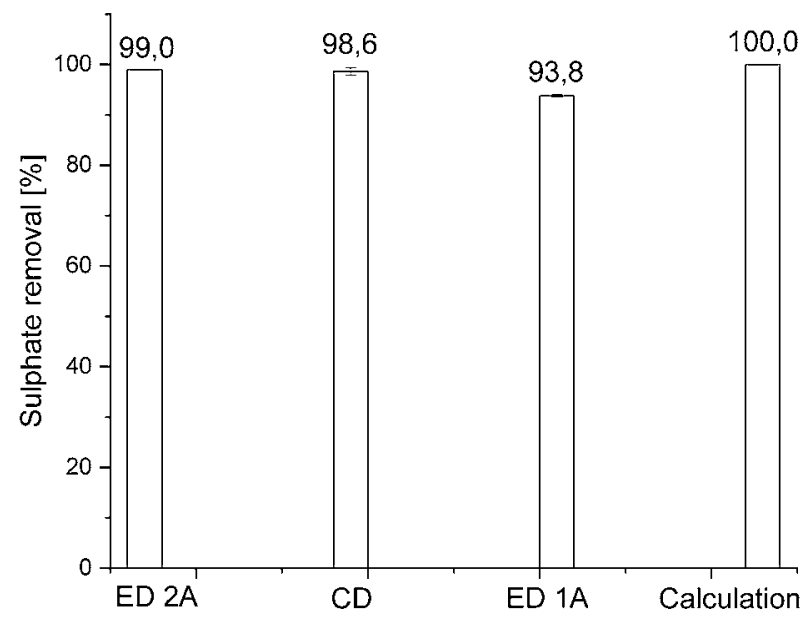

Fig. 4. Sulphate removal from mine water using the electrochemical dosing (ED) and chemical dosing (CD) of aluminium in ettringite precipitation. Error bars represent standard deviation $(n=2)$.

even though the parameters were chosen so that the theoretical dissolved aluminium amount was the same across both experiments. Kruk et al [34] reported a similar observation, with an increase in struvite purity and phosphate removal with a higher current density in electrochemical magnesium dosing during struvite precipitation. The dissolved aluminium amount was confirmed by weighing the aluminium electrodes before and after the experiments. Additionally, residual aluminium concentrations were less than $1.5 \mathrm{mg} \mathrm{L}^{-1}$ after treatment with the electrochemical aluminium dosage, and no aluminium-containing solid phases were detected with XRD analysis from the precipitated solids. The residual calcium concentration was same as the initial calcium concentration (approximately $300 \mathrm{mg} \mathrm{L}^{-1}$ ), which indicated that all the added calcium reacted during the ettringite precipitation.

\subsection{Precipitate purity}

Ettringite (ICDD 04-013-3691) and calcite (ICDD 04-0660867) peaks were identified from the XRD spectra of the precipitates in the electrochemical aluminium dosage experiments using 1 and 2 A electric currents as well as from the chemical aluminium dosing experiments (Fig. 5). From the XRD pattern, it is clear that all peaks matched well with the standard ICDD file 04-013-3691 of ettringite. The peaks also matched with the ICDD 04-066-0867 file of calcite. The highest peak of calcite $\left(\begin{array}{lll}1 & 0 & 4\end{array}\right)$ at $2 \theta$ of $29.4^{\circ}$ overlapped with the ettringite $(-2-14)$ peak. The other main peaks of calcite overlapped with those of ettringite as well. For example, calcite $\left(\begin{array}{lll}1 & 1 & 3\end{array}\right)$ overlapped with ettringite $\left(\begin{array}{lll}-3 & -1 & 5\end{array}\right)$ at $2 \theta$ of $39.4^{\circ}$, calcite $\left(\begin{array}{ll}2 & 0\end{array}\right)$ with ettringite $\left(\begin{array}{lll}1 & 0 & 10\end{array}\right)$ at $43.1^{\circ}$, calcite $\left(\begin{array}{lll}0 & 1 & 8\end{array}\right)$ with ettringite $\left(\begin{array}{lll}5 & 0 & 2\end{array}\right)$ at $47.5^{\circ}$, and calcite $\left(\begin{array}{ll}1 & 1\end{array}\right)$ with ettringite $\left(\begin{array}{ll}5 & 0\end{array}\right)$ at $48.5^{\circ}$. The amounts of ettringite and calcite in the solid samples were determined with full-pattern quantitative Rietveld analysis. The percentage amounts in the precipitates of the electrochemical (1 A current), electrochemical (2 A current), and chemical ettringite precipitation 


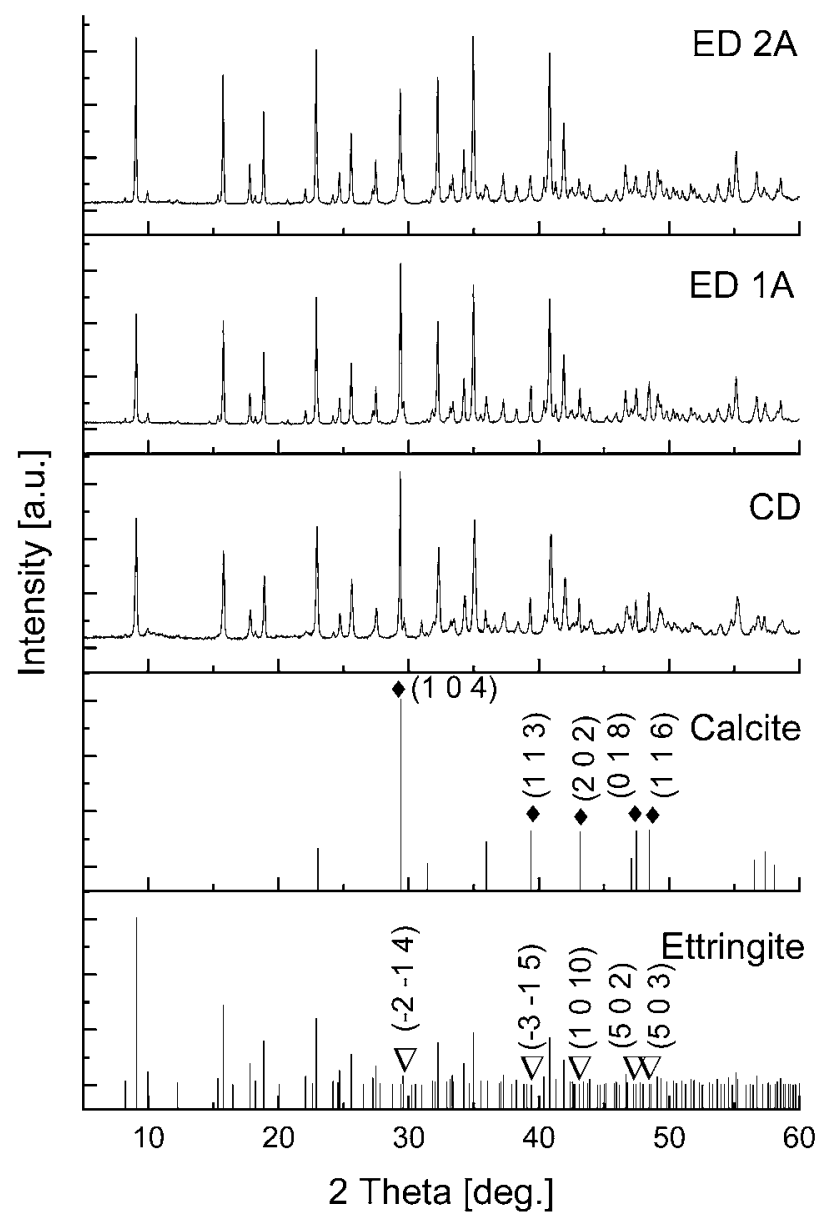

Fig. 5. XRD spectra of precipitates from electrochemical and chemical aluminium dosage experiments with mine water. $\mathrm{CD}=$ chemical dosage, $\mathrm{ED}=$ electrochemical dosage.

experiments were $89.5 \%, 92.5 \%$, and $92.6 \%$ ettringite and $10.5 \%, 7.5 \%$, and $7.4 \%$ calcite, respectively. The purity of the ettringite precipitates in the electrochemical and chemical ettringite precipitation experiments was in the same region as in previous chemical ettringite precipitation experiments by Tolonen et al. [19].

\subsection{Leaching experiments}

Stability is important when considering the disposal or even possible utilisation of the ettringite precipitate formed from mine water treatment. During the leaching experiments, some of the ettringite was found to decompose, which was detected through the rise in the sulphate, calcium, and aluminium concentrations in the water (Table 1). The leached sulphate concentrations were compared with the limits imposed by the Finnish government for waste disposal to waste and hazardous waste landfills (decree 331/2013). The sulphate concentrations leached out of the ettringite precipitates from the electrochemical and chemical aluminium dosage experiments were below the limits for waste disposal to waste landfills. However, as ettringite stability was tested, only calcium, aluminium, and sulphate were analysed from the water samples. In order to verify the suitability of the ettringite precipitate for disposal at a landfill, also $\mathrm{As}, \mathrm{Ba}, \mathrm{Cd}$, Crtot, $\mathrm{Cu}, \mathrm{Hg}$, $\mathrm{Mo}$, $\mathrm{Ni}, \mathrm{Pb}, \mathrm{Sb}, \mathrm{Se}, \mathrm{Zn}, \mathrm{Cl}, \mathrm{F}$, phenol index, dissolved oxygen carbon, and total dissolved solids should be analysed.

\subsection{Comparison of electrochemical and chemical ettringite precipitation}

In both the electrochemical and chemical aluminium dosing experiments, low residual sulphate concentrations close to the theoretical value were achieved. The produced solids before dewatering were found to be less voluminous in the electrochemical than in the chemical aluminium dosing experiments. Also, the solids were found to settle more quickly in the electrochemical rather than the chemical aluminium dosing experiments, with settling times of approximately $15 \mathrm{~min}$ and $1 \mathrm{~h}$, respectively. This could be due to the continuous aluminium dosage during the electrochemical dissolution compared to the one-time aluminium salt dosage. The continuous dosage can lead to low supersaturation and the growth of larger, more easily settling crystals. Similarly, electrocoagulation is known to form less voluminous solids than chemical coagulation [35]. No significant difference was observed in the weight of the dried ettringite precipitates between the electrochemical and chemical aluminium dosage experiments.

A preliminary cost comparison of mine water treatment by ettringite precipitation using electrochemical aluminium dosing with 2 A current and the direct dosing of $\mathrm{NaAlO}_{2}$ was conducted, as they achieved the same degree of sulphate removal and formed ettringite purity (Table 2). The operation costs of mine water treatment via ettringite precipitation with electrochemical and chemical aluminium dosing were approximately 2.43 and $2.33 € \mathrm{~m}^{-3}$ respectively. The cost of the ettringite produced was calculated by dividing the operational cost of the mine water treatment with the amount of ettringite produced in the treatment. Thus, the cost of the ettringite produced was estimated to be $0.42 € \mathrm{~kg}^{-1}$ ettringite and $0.40 € \mathrm{~kg}^{-1}$ ettringite for the electrochemical dosing and chemical dosing, respectively. The aluminium cost of the consumed aluminium electrode in the ettringite precipitation was found to be cheaper than the cost of the consumed sodium aluminate. Moreover, the aluminium cost of the electrochemical ettringite precipitation was calculated based on the consumed aluminium electrode and did not take into account that usually all of the electrode cannot be consumed. The calcium hydroxide cost was the same in both the chemical and electrochemical ettringite precipitation. In the electrochemical ettringite precipitation, the electric power cost for the dissolution of the aluminium electrode added to the cost of the treatment. Thus, the operational cost of ettringite precipitation with the electrochemical dosing of aluminium from a sacrificial aluminium anode was found to be more expensive than that with sodium aluminate dosing. Even though the cost of the ettringite precipitation with electrochemical aluminium dosing was higher, the handling of the aluminium as plates is easier compared to that of the aluminium as salt. Also, when aluminium is dosed electrochemically and not by using sodium aluminate salt, no sodium is added 
Table 1

Calcium, aluminium, and sulphate concentrations leached out of the ettringite precipitates from the electrochemical and chemical aluminium dosage experiments with mine water

\begin{tabular}{llll}
\hline Sample & $\mathrm{Al}(\mathrm{mg} / \mathrm{kg})$ & $\mathrm{Ca}(\mathrm{mg} / \mathrm{kg})$ & Sulphate $(\mathrm{mg} / \mathrm{kg})$ \\
\hline ED 2A & 57 & 6,915 & 18,243 \\
ED 1A & 188 & 6,815 & 17,120 \\
CD & 259 & 1,530 & 5,496 \\
Limit for waste landfill & & & 20,000 \\
Limit for hazardous waste landfill & & & 50,000
\end{tabular}

Concentrations are expressed as $\mathrm{mg} / \mathrm{kg}$ of dry ettringite.

$\mathrm{CD}=$ chemical dosage; $\mathrm{ED}=$ electrochemical dosage .

Table 2

Comparison of ettringite precipitation results using electrochemical dosing (ED) and chemical aluminium dosing (CD)

\begin{tabular}{lllll}
\hline Treatment & $\begin{array}{l}\text { Sulphate } \\
\text { removal (\%) }\end{array}$ & $\begin{array}{l}\text { Purity of ettringite } \\
\text { precipitate }(\%)\end{array}$ & $\begin{array}{l}\text { Cost } \\
\left(€ \mathrm{~kg}^{-1} \text { ettringite }\right)\end{array}$ & $\begin{array}{l}\text { Cost } \\
\left(€ \mathrm{~m}^{-3}{ }_{\text {mine water }}\right)\end{array}$ \\
\hline ED 2A & 99.0 & 92.5 & 0.42 & 2.43 \\
CD & 98.6 & 92.6 & 0.40 & 2.33 \\
\hline
\end{tabular}

$\mathrm{CD}=$ chemical dosage; $\mathrm{ED}=$ electrochemical dosage.

and thus no sodium is remained in the purified water. The increase in the sodium concentration in water treated with the chemical ettringite precipitation using sodium aluminate as the aluminium source has been reported earlier by Tolonen et al. [19]. Sodium remaining in the purified water increases the conductivity of the water. This can be problematic, as the amount of total dissolved solids, which, in practice, is measured based on conductivity, can be regulated in mine water discharge. Also, less voluminous sludge formed in electrochemical ettringite precipitation is beneficial. However, some operational problems, such as mineral deposition on the electrodes, exist when using electrochemical aluminium dosing. Polarity reversal during operation as well as acid washing between experiments can be used to remove mineral deposition. Even though, in this research, the cost of electrochemical aluminium dosing was slightly higher than the cost of aluminium salt, the energy cost could be lowered by the further optimization of the treatment process.

\section{Conclusions}

Electrochemical aluminium dissolution was found to be one alternative to aluminium salt dosing in ettringite precipitation, with a $99 \%$ sulphate removal efficiency from an initial 1,060 $\pm 20 \mathrm{mg} \mathrm{L}^{-1}$ mine water sulphate concentration using a $28 \mathrm{~mA} \mathrm{~cm}^{-2}$ current density compared to theoretical $100 \%$ and chemical $98.6 \%$ sulphate removal. High-purity ettringite was formed during both electrochemical precipitation with a $28 \mathrm{~mA} \mathrm{~cm}^{-2}$ current density and chemical precipitation ( $92.5 \%$ and $92.6 \%$ respectively). The main advantages of using an aluminium electrode as the aluminium source compared to chemical aluminium dosing are the ease of handling, more dense precipitate formation, and quicker settling. Additionally, when dosing aluminium electrochemically, only aluminium-and

no counterions $\left(\mathrm{Na}^{+}\right)$- are added to the water, as in the case of aluminium salt dosing.

\section{Acknowledgments}

The authors would like to thank Ilkka Vesavaara for ICP-OES analysis and Joost Caeyers, Pablo Hiller Vallina, Samuel Domec, and Leonie Hennemeyer for their assistance in conducting part of the laboratory experiments.

\section{Symbols} b c

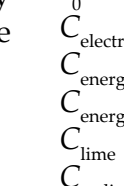

$C_{\text {sodium aluminate }}$

$C_{\text {sulphite }}$ sodiuminate

d sulphate

$$
\begin{aligned}
& C_{\text {Sod }} \\
& C^{2} \\
& d \\
& d \\
& F \\
& I \\
& I \\
& I \\
& k \\
& M
\end{aligned}
$$




\section{References}

[1] D. Barrie Johnson, K.B. Hallberg, Acid mine drainage remediation options: a review, Sci. Total Environ., 338 (2005) $3-14$.

[2] R.J. Bowell, A Review of Sulphate Removal Options for Mine Waters, A.P. Jarvis, B.A. Dudgeon, P.L. Younger, Eds., Mine Water 2004 - Proceedings International Mine Water Association Symposium 2, Proceedings-IMWA 2004, Newcastle Upon Tyne (University of Newcastle), 2004, pp. 75-91.

[3] M. Brown, B. Barley, H. Wood, Minewater Treatment: Technology, Application and Policy, IWA Publishing, London, 2002.

[4] N.F. Gray, Environmental impact and remediation of acid mine drainage: a management problem, Environ. Geol., 30 (1997) 62-71.

[5] M. Cañedo-Argüelles, B.J. Kefford, C. Piscart, N. Prat, R.B. Schäfer, C.-J. Schulz, Salinisation of rivers: an urgent ecological issue, Environ. Pollut., 173 (2013) 157-167.

[6] M.C. Moncur, C.J. Ptacek, D.W. Blowes, J.L. Jambor, Spatial variations in water composition at a northern Canadian lake impacted by mine drainage, Appl. Geochem., 21 (2006) 1799-1817.

[7] B. Boehrer, M. Schultze, Stratification of lakes, Rev. Geophys., 46 (2008), https://doi.org/10.1029/2006RG000210.

[8] C.T. Benatti, C.R.G. Tavares, E. Lenzi, Sulphate removal from waste chemicals by precipitation, J. Environ. Manage., 90 (2009) 504-511.

[9] B.G. Lottermoser, Mine Wastes: Characterization, Treatment and Environmental Impacts, Springer, New York, 2010.

[10] H. Runtti, E.-T. Tolonen, S. Tuomikoski, T. Luukkonen, U. Lassi, How to tackle the stringent sulphate removal requirements in mine water treatment-a review of potential methods, Environ. Res., 167 (2018) 207-222.

[11] W.X. Dou, Z. Zhou, L.-M. Jiang, A.J. Jiang, R.W. Huang, X. Tian, W. Zhang, D.Q. Chen, Sulphate removal from wastewater using ettringite precipitation: magnesium ion inhibition and process optimization, J. Environ. Manage., 196 (2017) 518-526.

[12] D.J. Sapsford, S. Tufvesson, Properties of recycled sludge formed from different aluminiferous reagents during the ettringite process, J. Water Process Eng., 19 (2017) 305-311.

[13] A. Abdel-Wahab, B. Batchelor, J. Schwantes, An equilibrium model for chloride removal from recycled cooling water using the ultra-high lime with aluminium process, Water Environ. Res., 77 (2005) 3059-3065.

[14] A. Abdel-Wahab, B. Batchelor, Effects of $\mathrm{pH}$, temperature, and water quality on chloride removal with ultra-high lime with aluminium process, Water Environ. Res., 78 (2006) 930-937.

[15] A. Abdel-Wahab, B. Batchelor, Interactions between chloride and sulphate or silica removals using an advanced limealuminium softening process, Water Environ. Res., 78 (2006) 2474-2479.

[16] I. Kabdaşlı, A. Bilgin, O. Tünay, Sulphate control by ettringite precipitation in textile industry wastewaters, Environ. Technol., 37 (2016) 446-451.

[17] A.J. Geldenhuys, J.P. Maree, M. de Beer, P. Hlabela, An integrated limestone/lime process for partial sulphate removal, J. S. Afr. Inst. Min. Metall., 103 (2003) 345-354.

[18] E.-T. Tolonen, T. Luukkonen, H. Runtti, J. Rämö, U. Lassi, Sorption of Arsenate on Ettringite Formed in Sulphate Removal from Mine Drainage Water, Proceedings IMWA 2016 Mining Meets Water - Conflicts and Solutions, Freiberg/Germany, 2016, pp. 867-873.
[19] E.-T. Tolonen, T. Hu, J. Rämö, U. Lassi, The removal of sulphate from mine water by precipitation as ettringite and the utilisation of the precipitate as a sorbent for arsenate removal, J. Environ. Manage., 181 (2016) 856-862.

[20] Council Directive 98/83/EC of 3 November 1998 on the Quality of Water Intended for Human Consumption, 1998.

[21] T. van der Meer, L. Nevatalo, J. Tanninen, Method of Treating Industrial Water, 2014.

[22] E.-T. Nurmesniemi, T. Hu, K. Rajaniemi, U. Lassi, Ettringite Precipitation from Mine Water with Electrochemical Aluminium Dosing, Proceedings of IWA Resource Recovery Conference 2019, 2019, pp. 562-563.

[23] T. Luukkonen, H. Runtti, M. Niskanen, E.-T. Tolonen, M. Sarkkinen, K. Kemppainen, J. Rämö, U. Lassi, Simultaneous removal of $\mathrm{Ni}(\mathrm{II}), \mathrm{As}(\mathrm{III})$, and $\mathrm{Sb}(\mathrm{III})$ from spiked mine effluent with metakaolin and blast-furnace-slag geopolymers, J. Environ. Manage., 166 (2016) 579-588.

[24] ASTM B317, Standard Specification for Aluminium-Alloy Extruded Bar, Rod, Tube, Pipe, Structural Profiles, and Profiles for Electrical Purposes (Bus Conductor), 2015.

[25] T.R. Devlin, M.S. Kowalski, E. Pagaduan, X. Zhang, V. Wei, J.A. Oleszkiewicz, Electrocoagulation of wastewater using aluminium, iron, and magnesium electrodes, J. Hazard. Mater., 368 (2019) 862-868.

[26] J.N. Hakizimana, B. Gourich, M. Chafi, Y. Stiriba, C. Vial, P. Drogui, J. Naja, Electrocoagulation process in water treatment: a review of electrocoagulation modeling approaches, Desalination, 404 (2017) 1-21.

[27] O. Sahu, Suitability of aluminium material on sugar industry wastewater with chemical and electrochemical treatment processes, Int. J. Ind. Chem., 10 (2019) 335-347.

[28] A. Hug, K.M. Udert, Struvite precipitation from urine with electrochemical magnesium dosage, Water Res., 47 (2013) 289-299.

[29] SFS, SFS-EN 12457-2 Characterisation of Waste, Leaching. Compliance Test for Leaching of Granular Waste Materials and Sludges. Part 2: One Stage Batch Test at a Liquid to Solid Ratio of 10 1/kg for Materials with Particle Size Below $4 \mathrm{~mm}$ (Without or With Size Reduction), 2002.

[30] S.C.B. Myneni, S.J. Traina, T.J. Logan, Ettringite solubility and geochemistry of the $\mathrm{Ca}(\mathrm{OH})_{2}-\mathrm{Al}_{2}\left(\mathrm{SO}_{4}\right)_{3}-\mathrm{H}_{2} \mathrm{O}$ system at 1 atm pressure and 298 K, Chem. Geol., 148 (1998) 1-19.

[31] C.L. Perrin, Linear or nonlinear least-squares analysis of kinetic data?, J. Chem. Educ., 94 (2017) 669-672.

[32] E. Demirbas, M. Kobya, Operating cost and treatment of metalworking fluid wastewater by chemical coagulation and electrocoagulation processes, Process Saf. Environ. Prot., 105 (2017) 79-90.

[33] A.M. Cody, H. Lee, R.D. Cody, P.G. Spry, The effects of chemical environment on the nucleation, growth, and stability of ettringite $\left[\mathrm{Ca}_{3} \mathrm{Al}(\mathrm{OH})_{6}\right]_{2}\left(\mathrm{SO}_{4}\right)_{3} \cdot 26 \mathrm{H}_{2} \mathrm{O}$, Cem. Concr. Res., 34 (2004) 869-881.

[34] D.J. Kruk, M. Elektorowicz, J.A. Oleszkiewicz, Struvite precipitation and phosphorus removal using magnesium sacrificial anode, Chemosphere, 101 (2014) 28-33.

[35] M.Y.A. Mollah, P. Morkovsky, J.A.G. Gomes, M. Kesmez, J. Parga, D.L. Cocke, Fundamentals, present and future perspectives of electrocoagulation, J. Hazard. Mater., 114 (2004) 199-210. 